\title{
Implementation difficulties of tutor support technologies in higher education
}

\section{Dificultades de implementación de las tecnologías de apoyo al tutor en la educación superior}

\author{
Solovyeva Natalia \\ Perm State National Research University, Russia \\ Cirkunova Larisa \\ Perm State National Research University, Russia \\ Tihomirova Larisa \\ Perm State National Research University, Russia \\ Chernousova Anastasia \\ Perm State National Research University, Russia \\ Kurzenkova Elena \\ Perm State National Research University, Russia
}

Received 08-12-20 Revised 09-30-20

Accepted 10-13-20 On line 01-12-21

*Correspondence

Email: tikhomirova.lar@yandex.ru
Cite as:

Natalia, S. Larisa C, Larisa C, Anastasia C, \& Elena K, (2020 Implementation difficulties of tutor support technologies in higher education. Propósitos y Representaciones, 9 (SPE1), e855. Doi: http://dx.doi.org/10.20511/pyr2021.v9nSPE1.e855 


\section{Summary}

The article is devoted to problems of implementation in practice of the University of technology tutor support, which would allow modern students to quickly and painlessly build an individual trajectory of personal and professional development, and University - to implement the requirements of standard of the last generation. The article is based on observations of the included experiment on the implementation of tutor support, which was carried out in the framework of advanced training courses for teachers of PSNIU. During the experiment, conditions that are extremely important for ensuring the effectiveness of the implementation of tutor support technology were identified. Among them: the certainty (firmness) of the tutor's position in the implementation of a specific goal of tutor support; the importance of organizing spatial interaction during the tutorial; the formation of an adequate understanding of the content of the tutor's activity among the participants of the tutorial; recognition of the self-value of the tutor's activity.

Keywords: tutoring, University, tutor support, activity

\section{Resumen}

El artículo está dedicado a los problemas de implementación en la práctica del apoyo del tutor de tecnología de la Universidad, lo que permitiría a los estudiantes modernos construir de manera rápida y sin dolor una trayectoria individual de desarrollo personal y profesional, y Universidad para implementar los requisitos de estándar de la última generación. . El artículo se basa en las observaciones del experimento incluido sobre la implementación del apoyo del tutor, que se llevó a cabo en el marco de los cursos de formación avanzada para docentes del PSNIU. Durante el experimento, se identificaron las condiciones que son de suma importancia para asegurar la efectividad de la implementación de la tecnología de apoyo al tutor. Entre ellos: la certeza (firmeza) de la posición del tutor en la implementación de un objetivo específico de apoyo del tutor; la importancia de organizar la interacción espacial durante el tutorial; la formación de un conocimiento adecuado del contenido de la actividad del tutor entre los participantes de la tutoría; reconocimiento de la autovaloración de la actividad del tutor.

Palabras clave: tutoría, Universidad, apoyo del tutor, actividad.

\section{Introduction}

The idea of tutor support technology introduction into the practice of university education is currently capturing an increasing number of minds. Originating in Europe during the 12th-14th centuries, which took shape as an independent profession in Oxford and Cambridge, tutoring appeared in Russia during the late 80-ies of the XX-th century [Kozar, 2013. Xiao, 2012] (remember the first competition of tutors in Russia, conducted in 1989 by P.G. Shchedrovitsky, the head of the "Cultural policy school"). In the Russian Federation the theoretical and practical aspects of tutor support problems were studied by A.I. Adamsky, T.M. Kovaleva [Kozar, 2013], A.N. Tubelsky, M.P. Cheremnykh, P.G. Shchedrovitsky and others [Kovaleva, 2012, Medeshova, Amanturlina, \& Sumyanova, 2016, Heydmets, 1979].

Today, a tutor in the Russian Federation is a teacher who acts on the principle of individualization and accompanies the construction of his own individual educational program for students (T.M. Kovaleva). Tutoring support is a pedagogical activity for the individualization of education, aimed at student educational motives and interest identification and development, the search for educational resources to create an individual educational trajectory [Medeshova, Amanturlina, \& Sumyanova, 2016: 177].

In the general pedagogical sense, tutoring can be implemented in a general education school, lyceum, gymnasium, additional education institution, kindergarten, college, university, in 
advanced training courses, even in a family. But it arises only where and when there is a need and the necessary conditions for the transition to variability and individualization of educational programs.

Unfortunately, it is precisely the lack of administrative and regulatory and organizational frameworks for the transition to variability and individualization of educational programs that does not allow the introduction of tutoring support in universities everywhere.

Nevertheless, within the framework of the training programs for tutors, which are currently being implemented at various courses for raising the qualifications of teachers, practical work is carried out, the technology of tutor support is being tested in full or in part. Nowadays this activity allows to identify many difficulties and surprises in tutor support, explained by the peculiarities of the Russian mentality, the traditions of relationships along the lines of "teacher-student", "senior-junior", "administration-students", etc.

Analysis methods. The study of tutor support technology implementation difficulties at a university is based on the method of analytical analysis of the literature on the research topic, the method of an included experiment, during and after which they analyzed the feelings of psychological comfort arising or disappearing in a tutor from communication with students. The method of questioning the tutors was also used.

\section{Research part}

The study of the tutor's practical activities at a university (during the course of tutorials) showed that important conditions to ensure the effectiveness of the tutor support technology implementation are the following ones:

1. Certainty (firmness) of the tutor's position during the implementation of tutor support specific goal. The activities of a tutor are based on the goals that are different from educational (solved by a university teacher), pedagogic (solved by a student group curator) and administrative and organizational (solved by the dean's office). During a lesson, a teacher implements a separate element of training in the form of a topic or a series of questions that are included in the training program, which is the reflection of society social order. A tutor proceeds from student's interests, helping him to implement his educational goals. A tutor transfers an individual interest of a ward into the initiation of a specific activity, which "is possible as his educational or social test" [Leathers, 2017: 34]. The tutor's task is to help a student understand what is interesting to him and how he can implement his interest in the educational present and the current educational (professional) future. The certainty (firmness) of a tutor's position in the implementation of this specific goal acquires special significance in real practice and is understood not as "rigidity", harshness, rudeness or inflexibility of a tutor's pedagogical position, but as decisiveness, adherence to principles, the ability to say "no" when a student tries to leave own activity and replace it with the fulfillment of the tutor's requirements or advice.

The position firmness is necessary for a tutor when he develops the boundaries of communication not only with the students, but also in relation to the "administrative orders" of the dean's office. A tutor should not fulfill the "requests" of the dean's office (or other administrative bodies) and use tutorials for any other, "non-tutor" purposes (meetings, questionnaires, opinion polls, etc.). As the substitution result, the students lose confidence in the tutor, begin to regard the tutorial negatively as a form of communication with a tutor.

From the diary of observations: "The dean's office asked to give the beginning of the tutorial for the meeting of students with the representatives of the Department of Foreign Languages, they asked that students come. I agreed. And I made a mistake, because after this meeting the students were annoyed and the tutorial "failed" (Tutorial \# 5)."

2. Rational organization of spatial interaction during the tutorial. Spatial contact during the tutorial is a prerequisite for communication; the organization of any interpersonal relationship is carried out primarily through spatial interactions, which are cognizable and changeable [Heydmets, 1979]. Spatial behavior can influence the communication process, and this is important to consider when they conduct tutorials, and especially the first tutorial on acquaintance. 
According to the theory of the American psychologist Edward Hall [Hall, 1990], the foundation of the entire system of interaction is the distance between the subjects of communication. The scholar suggested that, regardless of cultural characteristics, national traditions, etc. any communication subject has his own personal territory, which he defines for himself. Each person has his own field, his own aura, the violation of which in specific situations means harming the cause. The violation of the distance can be carried out in various ways.

A) During the first tutorial. According to E. Hall, "the remoteness of the subjects is most important during the perceptual stage, when the interlocutors just begin to understand each other" [Hall, 1990: 122].

From the observation diary: "During the first tutorial, the space in which I found myself with the students did not imply the required distance between us. People unfamiliar to each other (tutor and students) found themselves at a round table. A round table (informal) creates an atmosphere of informality and ease (or even optionality?), and it is best to hold conversations for the people of the same social status, since each person occupies the same territory on the table. The round table is convenient when relationships with students have already been developed. During the very first tutorial it was not easy for me to be in the circle of students, there was no necessary (at least personal) distance between me and the students. It was difficult to overcome excitement and introduce myself, because there were strangers in my intimate space and I needed to inspire trust in them. Borders were violated not only for me, but also for the students sitting next to me.

B) The aspect of social and age differentiation. The greater the age difference among communicating people, the more important is the distance between them. During communication with peers, we are located somewhat closer than during communication with much older person. Likewise, when they deal with a person of a higher social status. The Australian psychologist Paul $\mathrm{R}$. Wilson showed that "the growth of a person in the eyes of outsiders is not always equal to the actual, but often depends on a person's social status" [Medeshova, Amanturlina, \& Sumyanova, 2016: 176].

C) the location of the tutorial participants.

From the observation diary: "The students participated in the tutorial at will, but the position "opposite each other" put pressure on them. A better position would be a 90-degree angle that allows the other person to think and act independently without any non-verbal pressure from you." It was found that, all other things being equal, the conflicts with such an arrangement occur less frequently than among those who sit opposite each other. If a participant's task is to provoke a conflict, then you can sit directly opposite your opponent. It is no coincidence that the word "confrontation" has two meanings: "location opposite each other" and "conflict".

Thus, the optimal minimum distance between a tutor and students during the first lesson is within the boundary between the personal and social zones. During further communication, these boundaries can be changed.

3. Formation of an adequate understanding of tutoring activity content among the tutorial participants. Since the first lesson, students should have an idea of tutoring meaning.

Analyzing the questionnaires of the first tutorial, we found that students expect a tutor to perform informational, organizational and even administrative activities (up to organizing the trips to exhibitions, theaters, etc. for them). It turns out exactly what the tutor should leave, on the contrary.

From the diary of observations: "Many have indicated the desired trend of their development - "creative", meaning by it the desire to "learn to play musical instruments", "to learn acting." Yes, a tutor can work with any requests, but during the first tutorial, such requests arose because, as a tutor, I was unable to present the students the position of a tutor only. Presenting the tutor competence to students allows them to understand the difference between a tutor and a teacher, a tutor and a psychologist, etc. A novice tutor does not always succeed, helping "in a tutor's way". At first it was difficult for me too."

Any request, complaint, manipulation on the part of a tutor should be transferred into practical action, you need to help with questions, not advice and actions. From the observation diary: "My wards started asking for advice (and complaining) what to do if a teacher does not show mistakes in the tests, and they do not agree with the number of points. Is it correct? I did 
not evaluate the system of the teacher's work, I asked what they were doing. They answered that they approached the teacher. And I asked how many times they approached her. They said that only one time. I asked what else they were going to do. They answered that they would approach the teacher again (Tutorial No. 6).

"At first I asked how the things with the teacher "got on". It turned out that nothing had been changed, but they found out in the dean's office that there is a deadline for appealing the checkpoint results - 2 days (Tutorial No. 7)."

"I asked them about the trimester results. It turned out that the teacher gave them a good grade, because they attended all classes, worked to achieve the results and were persistent in their desire to improve the result. I praised them (Tutorial № 9).”

Let us recall that pedagogical support during a tutorial is not an impact on a tutor, but a kind of educational interaction with him, during which the student performs actions (selfeducational efforts), and the teacher creates conditions for the effective implementation of these actions [Zhigalev, Vikulina, Bezukladnikov, 2014: 358] ... When we advise, we take away from a person the opportunity to rely on himself, to develop inner qualities, to make the experience of decisions and their consequences more effective. Actually, we are fostering a dependent position. If a tutor begins to advise, he moves from the position of a tutor to the position of an ordinary consultant.

4. Implementation of voluntary participation principle in tutorials.

From the observation diary: "The lesson began with my great excitement. Only 2 students came. Naturally, I did not expect this. During the first minute, I didn't know what to do: let go or continue the tutorial. I decided to continue. And with every minute I realized that I did the right thing. One of my stereotypes that there should be a lot of students during a tutorial was shattered. No, there must be those who are interested in this, then the work will be interesting and of high quality (Tutorial No. 2)."

Do not hesitate to ask a student if he needs a tutorial, if he wants to develop. Attending a tutorial is a student's "act of goodwill". You should not, by hook or by crook, "lure" students into a tutorial. Nothing good will come of it. We will only provoke an undermining of trust in the tutor and the increase of tension in the relationship.

5. Recognition of the intrinsic value of tutoring by the teaching community and the administrative structures of the university. Recognition of tutoring as a full-fledged, independent type of pedagogical activity, very complex in content and with the obligatory allocation of time for tutorials in the lesson schedule is another condition for the successful implementation of tutor support technology at the university. Until the educational institution has a clear idea of the tutor's competence, what exactly the tutor should do, how important this activity is for the personal and professional development of students, there won't be the progress in the implementation of tutor support technology.

For example, if tutorials are not included in the schedule, then the impression is created that this is a completely optional activity that is not important for students.

\section{Conclusion}

Emphasizing the importance of the chosen field of research, let us recall the statement of the tutor movement ideologist in the Russian Federation T.M. Kovaleva that a tutor is guided by the "principle of openness of education, in which not only traditional institutions (kindergarten, school, university, etc.) have educational functions, but each element of the social and cultural environment can carry a certain educational effect, if used appropriately for this, expands the existing educational space of each student before transforming this space into an open one" [Kovaleva]. The goal of a tutor is to open up a whole world of educational opportunities for a student, the world in which he will feel confident and free.

\section{Acknowledgements}

The authors are grateful to N.V. Solovyova who provided the materials provided for the included experiment (observation diary) on organizing tutorials at Perm State National Research 
University. Her subtle remarks and accurate observations, as well as reflective reasoning helped to present a holistic picture of the student's tutoring organization.

\section{References}

Kozar, O. (2013). The face of private tutoring in Russia: Evidence from online marketing by private tutors. Research in Comparative and International Education, 8(1), 74-86.

Xiao, J. (2012). Tutors' influence on distance language students' learning motivation: voices from learners and tutors. Distance education, 33(3), 365-380.

Kovaleva T.M.(2012). Profession "Tutor". M., Publishing house: SFK - office. 245 p.

Medeshova, A., Amanturlina, G., \& Sumyanova, E. (2016). (2016) Volume 11 Issue 15. Development, 11(17), 1.

Heydmets, M.(1979). Spatial factor in interpersonal relations: an attempt to build a concept // Man, environment, space. Research on the psychological problems of the spatial-subject environment. Tartus: Tartu State un-ty, pp. 4-28.

Leathers, D.(2017). Successful Nonverbal Communication: Principles and Applications. University of Georgia, p. 176.

Hall E. T. (1990).Understanding Cultural Differences: Germans, French and Americans. Intereultural Press,

Zhigalev B.A., Vikulina V.A., Bezukladnikov K.E. (2014).Pedagogical Measuring Of Edukation Quality // Life Science Journal. V. 11. №7c. pp. 356-359. 